\title{
Goblet and Clara cells of human distal airways: evidence for smoking induced changes in their numbers
}

\author{
AB LUMSDEN, A McLEAN, D LAMB \\ From the Department of Pathology, University of Edinburgh
}

\begin{abstract}
The goblet cell and Clara cell populations of human distal airway epithelium were examined. The bronchioles, terminal bronchioles, and respiratory bronchioles of 16 smokers and four non-smokers were studied by both light and electron microscopy in surgically resected specimens. A very significantly $(p<0.001)$ greater number of goblet cells were found in the bronchioles of smokers compared than in those of non-smokers but no such difference was evident in terminal/respiratory bronchioles. Clara cell numbers in contrast were lower in the bronchioles $(p<0.01)$ and terminal and respiratory bronchioles of smokers $(p<0.01)$. Both of these alterations in cell frequency may adversely affect small airway function in smokers.
\end{abstract}

Goblet cells and Clara cells are recognised constituents of human airway epithelium. Whereas goblet cells occur mainly in proximal airways Clara cells reside more distally, in the smaller peripheral airways. The goblet cell serves as a mucus producing epithelial cell and is similar in appearance to the cells of the submocosal glands. The morphology of the goblet and of the Clara cell has been described in several previous studies both in the rat ${ }^{1}$ and in man. ${ }^{2}$ Factors affecting the number of goblet cells are a matter of some debate. It is known that goblet cell frequency can be influenced by many external agents-for example, nitrogen dioxide, sulphur dioxide, and cigarette smoke,,$^{3-5}$ as well as pharmacological agents such as isoprenaline and salbutamol. $^{6}$

The existing controversy over the role and classification of the Clara cell is dealt with in a recent review by Widdicombe. ${ }^{7}$ The main proposals concerning its role are that it is a producer of either surfactant $^{8}$ or a bronchiole-alveolar hypophase layer, ${ }^{4}$ as well as acting as a stem (progenitor) cell for the bronchiolar epithelium. ${ }^{10}$ Very little is understood about the control of Clara cell numbers but it has been shown that this may also be influenced by inhaled irritants. ${ }^{911}$

Address for reprint requests: Dr D Lamb, Department of Pathology, University of Edinburgh, Teviot Place, Edinburgh.

Accepted 4 June 1984
In this study we have concerned ourselves with human distal airways. We have reviewed the morphology of goblet and Clara cells by examination of $1 \mu \mathrm{m}$ araldite sections stained with toluidine blue and by electron microscopy. Using thin araldite sections, we have counted goblet and Clara cells in bronchioles and terminal and respiratory bronchioles. Finally, we have compared the results obtained from airways of smokers with those of non-smokers and shown significant differences in the values of goblet and Clara cells between these two groups.

\section{Methods}

The material used in this study consisted of human lung tissue removed at operation for carcinoma. Twenty cases were examined, of which 14 were pneumonectomy specimens and 6 lobectomy specimens. The lungs were fixed immediately on removal from the patient by a perfusion fixation procedure using $2 \%$ electron microscopy grade glutaraldehyde. The specimens were left for a further 24 hours before being sliced into $1 \mathrm{~cm}$ sagittal sections for routine pathological examination. Tissue blocks required for study were selected from areas showing (1) no blockage of associated bronchi by tumour, mucus, or pus; (2) no macroscopic evidence of previous or current infection; and (3) no obvious sign of tumour.

Tissue blocks were taken from a position $1-2 \mathrm{~cm}$ 


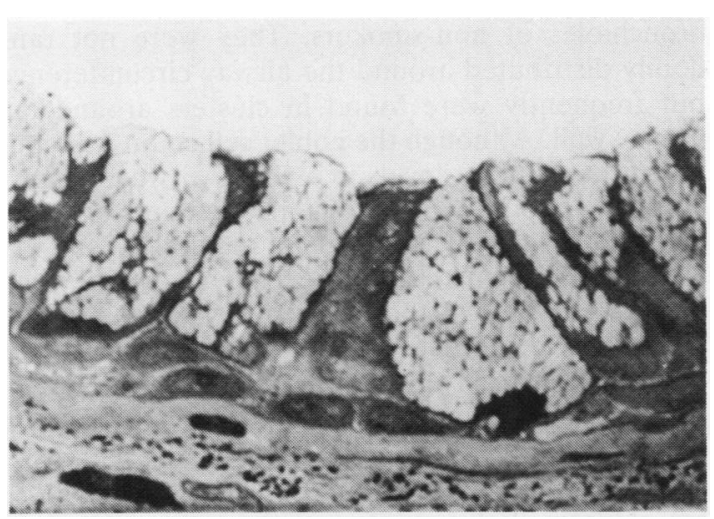

Fig 1 Numerous typical goblet cells filled with mucin granules as seen on 1 um araldite sections stained with toluidine blue. $(\times 610$.

from and parallel with the pleural surface of the lung. Each block was about $2.5 \times 1.5 \times 0.5 \mathrm{~cm}$ in size.

The tissue was processed by a modified electron microscopic technique, ${ }^{12}$ finally being impregnated and embedded in araldite.

Sections were cut at a thickness of $1 \mu \mathrm{m}$. Three sections were examined per airway at intervals of at least $10 \mu \mathrm{m}$. Areas required for electron microscopy were selected from these sections. Ultrathin sections were then prepared from the original tissue block and stained with uranyl nitrate/lead citrate.

The airway was classified as either a bronchiole or a terminal/respiratory bronchiole. A bronchiole was taken to be an airway of less than $3 \mathrm{~mm}$ in size with no cartilage or glands in its wall. Respiratory bronchioles were recognised by the alveoli arising from their walls. Reliable identification of terminal bronchioles was possible only when they were observed in continuity with respiratory bronchioles.

The area of epithelium to be studied was selected randomly. Cells were counted on each of 10 consecutive high power fields (about 300 cells) with one count on each of three sections per airway. One hundred and twenty airways were examined (five from each smoker, 10 from non-smokers), giving a total of about 90000 cells. Results were expressed as percentages of total epithelial cells.

Detailed smoking histories were obtained by distributing questionnaires to 17 of the 20 patients after their operation. In three cases this was not possible owing to the death of one patient at operation and to refusal of permission to approach the other two patients. Under these circumstances information was obtained from the clinical notes and general practitioners.
Statistical analysis was performed with the Mann-Whitney U test.

\section{Results}

\section{MORPHOLOGICAL APPEARANCES}

\section{Goblet cells}

On $1 \mu \mathrm{m}$ araldite sections stained with toluidine blue the goblet cell varied in appearance from the classical goblet shape to a tall columnar cell with a basal nucleus (fig 1). It extended from the basement membrane to the airway lumen, into which the cell apex frequently appeared to bulge. A characteristic feature of the cell was the presence of large, round secretory granules which filled the cytoplasm. The mucin vacuoles were variable in their staining characteristics, most frequently appearing pink in colour varying to dark blue.

By electron microscopy the goblet cell nucleus was a homogenous, electron dense, basally situated structure, in section measuring about $5 \times 5 \mu \mathrm{m}$. A few mitochondria were occasionally observed close to the nucleus. Golgi apparatus and endoplasmic reticulum were not consistently apparent, as the cytosol was in most cases completely filled with secretory granules.

The goblet cell granules were rounded in shape but were variable in both size (1-3 $\mu \mathrm{m})$ and electron density. All the granules were bound by a unit membrane and many of the more electron dense granules appeared to have a whorled substructure. Electron microscopy confirmed the frequent occurrence of an apical luminal bulge and revealed many surface microvillus processes. Normally goblet cells are readily recognised by both light and electron microscopy. In this study we encountered a small percentage $(<1 \%)$ of cells (in both smokers and non-smokers) which were not classifiable by light microscopy. Electron microscopic study of this group showed it to contain several different cell types. Some of these cells appeared to be goblet cells with only a small number of mucin granules. These may represent either young cells in the process of secretion synthesis or a postsecretory state.

\section{CLARA CELLS}

By light microscopy the Clara cell extended from the basement membrane to the airway lumen, into which a very conspicuous apical bulge protruded (fig 2). This apical protrusion was much more prominent than that of the goblet cell. Numerous small, blue black apical granules were also present.

By electron microscopy it was unusual to visualise a complete Clara cell. This gave the impression of the Clara as a long thin cell tapering from its apical cap to the basement membrane. The nucleus occur- 


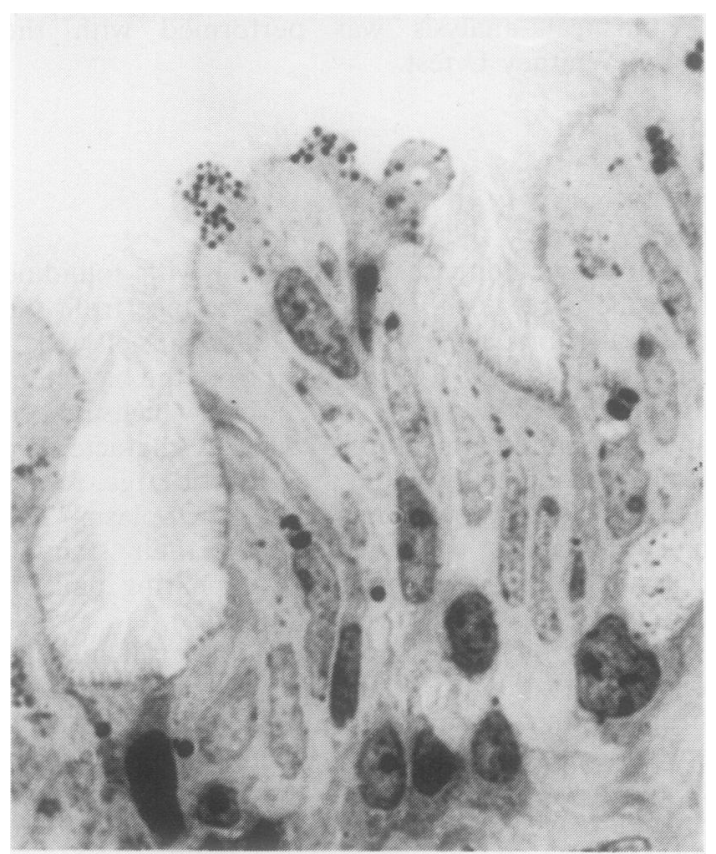

Fig 2 Typical Clara cells showing a prominent apical luminal bulge containing dense granules as seen in $1 \mathrm{\mu m}$ araldite sections stained with toluidine blue. $(\times 665$.)

red in the middle third and was oval in shape and elongated in the long axis of the cell, measuring about $5 \times 2 \mu \mathrm{m}$. Some chromatin clumping was noted around the nuclear margin. From our observations the Clara cell characteristically has an abundance of stacked smooth endoplasmic reticulum in its apical one third. This smooth endoplasmic reticulum occasionally showed areas of focal dilatation appearing as clefts in the cytoplasm. Rough endoplasmic reticulum was also present, though in much smaller quantities, and was in the inferior third of the cell. A few scattered mitochondria were found throughout, but were usually absent from the cell apex. The secretory granules of the Clara cell are confined to the apical bulge. They varied in number from zero to 20 per cell and were homogeneous, electron dense, and bound by a unit membrane. The granules varied in size from 0.1 to $0.5 \mu \mathrm{m}$ diameter. Numerous apical microvilli were also noted on the luminal bulge.

\section{CELL DISTRIBUTION AND NUMBER AND THE EFFECTS OF SMOKING \\ Goblet cells}

Goblet cells were consistently.identified in the bronchioles of smokers but in only about one third of the bronchioles of non-smokers. They were not randomly distributed around the airway circumference but frequently were found in clusters around the airway wall. Although the goblet cell count was consistent at different levels in a single airway, considerable variability was occasionally found between different bronchioles in a single patient.

In the bronchioles of smokers the mean goblet cell count was $6.7 \%$ of the total epithelial cells (range $0.04-19.6 \%$ ). In the non-smokers the mean was $1.2 \%$ of the total epithelial cells (range $0-3.5 \%$ ). This is a highly significant difference $(\mathrm{p}<0.001)$ (fig $3)$.

In terminal and respiratory bronchioles of smokers goblet cells constituted an average of $1.9 \%$ of epithelial cells (range 0-17\%). It should be emphasised that this value is greatly influenced by the high goblet cell count of $17 \%$ obtained from a single
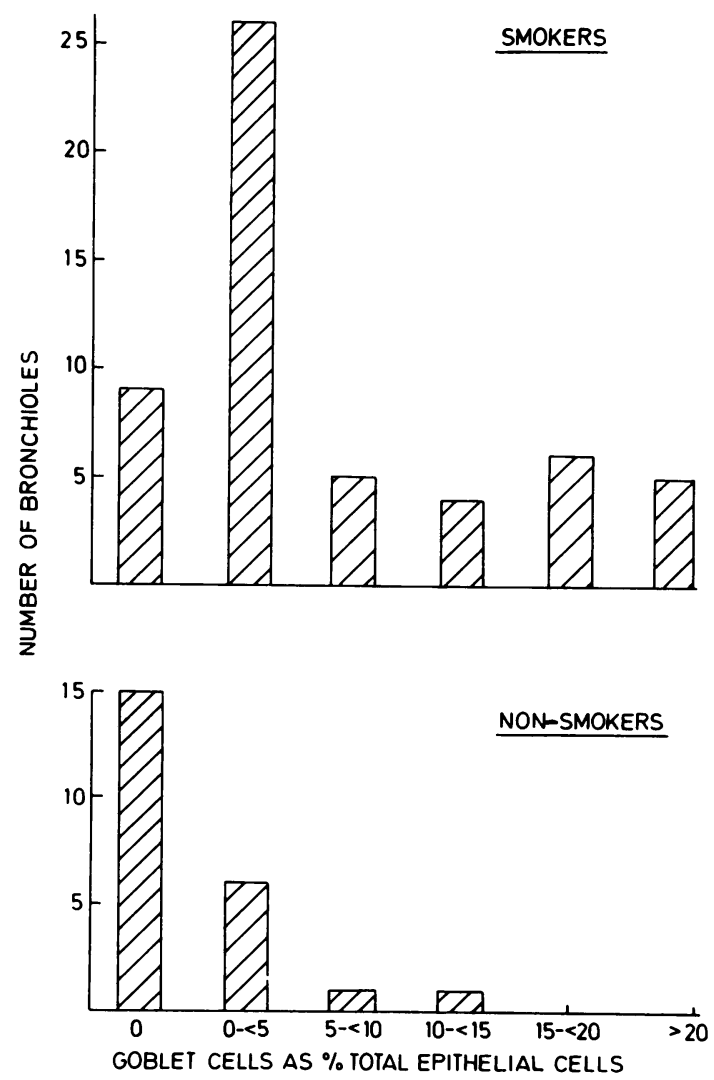

Fig 3 Goblet cell frequency as percentage of total epithelial cells per number of bronchioles examined. 

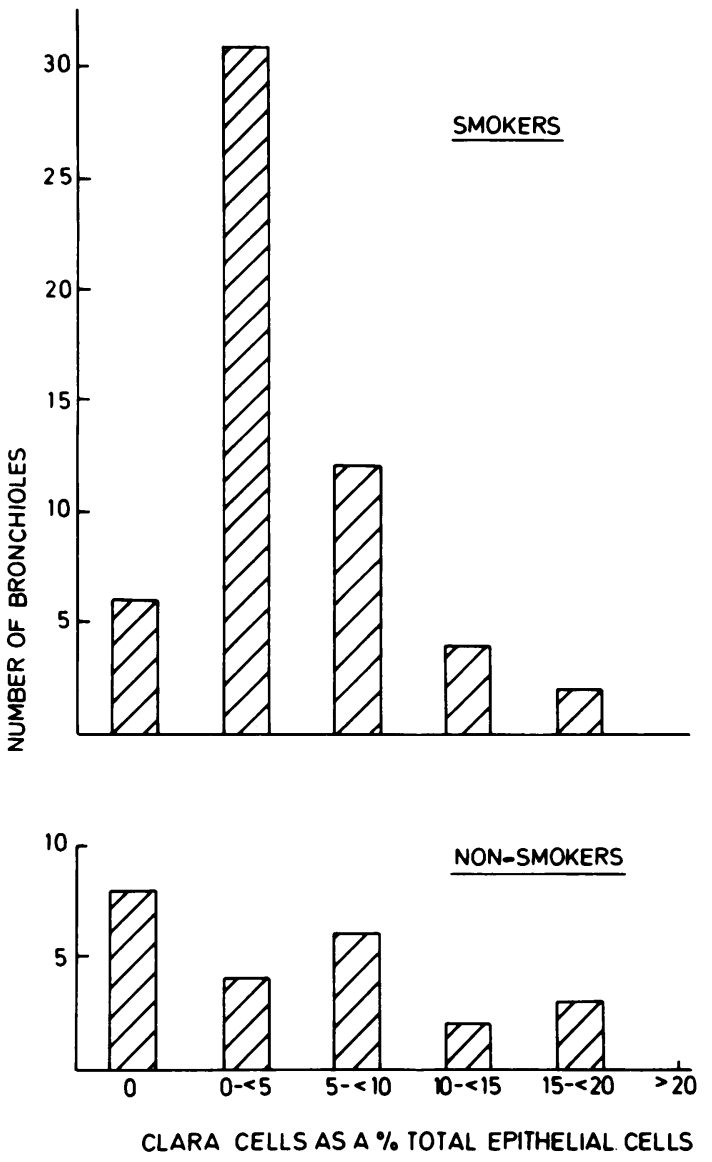

Fig 4 Clara cell frequency as percentage of total epithelial cells per number of bronchioles.

patient. In non-smokers goblet cells comprise a mean of $0.07 \%$ of the total epithelial cells (range $0-0.7 \%$ ). There is no significant difference between these two cell frequencies.

\section{CLARA CELLS}

Clara cells were identified in bronchioles, terminal bronchioles, and respiratory bronchioles in both smokers and non-smokers.

As with goblet cells, Clara cells were frequently found clustered together in small groups. In contrast, however, the Clara cell frequency was generally consistent at different levels in a single bronchiole, and also in different bronchioles within a single patient. In the bronchioles of smokers Clara cells comprised mean of $4.3 \%$ of the total epithelial cells (range $0-10 \cdot 4 \%$ ). In bronchioles of nonsmokers they comprised a mean of $8.3 \%$ of the total

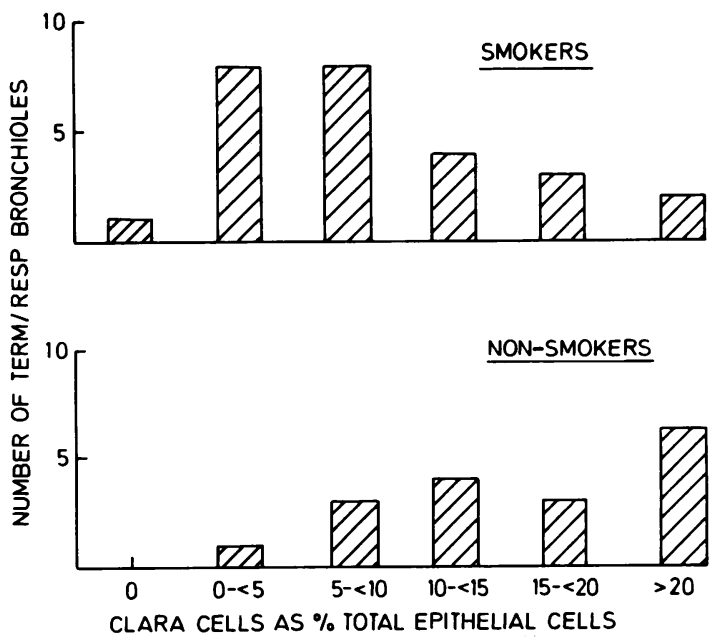

Fig 5 Clara cell frequency as percentage of total epithelial cells per number of terminal and respiratory bronchioles.

epithelial cells (range $2-13 \cdot 3 \%$ ). This difference was significant at the $p<0.01$ level (fig 4).

In terminal and respiratory bronchioles of smokers a mean of $8.0 \%$ of epithelial cells were Clara cells (range $4 \cdot 6-25 \cdot 6 \%$ ). In non-smokers the mean was $14.5 \%$ (range $1-30 \%$ ), a significant difference $(\mathrm{p}<0.01)$.

\section{Discussion}

Goblet cells are said to be very infrequent in peripheral airways of normal rats. ${ }^{13}$ In man they have been variously described as being absent from airways of under $2 \mathrm{~mm}^{13}$ or under $1 \mathrm{~mm} .^{14}$ In this study, however, we have demonstrated the occurrence of goblet cells in bronchioles and terminal bronchioles of smokers and non-smokers and in one case respiratory bronchioles of a smoker.

Very little is understood of the intrinsic mechanisms which control the size of a goblet cell population in normal man. Various animal models have been devised in an effort to understand the role of extrinsic agents. It has been shown that nitrous oxide $^{15}$ or sulphur dioxide ${ }^{10}$ inhalation in rats may cause goblet cell hyperplasia and peripheral extension of goblet cells. Furthermore, it has been demonstrated that administration of isoprenaline can produce similar changes. ${ }^{16}$

A more direct comparison can be made between the findings of the current study and of experiments on animal exposure to cigarette smoke, ${ }^{5}$ which also demonstrated the occurrence of goblet cell hyperplasia. It has further been shown that addition of the 
anti-inflammatory agent phenylmethyloxadiazole to tobacco can prevent this increase in goblet cell number in rats. ${ }^{17}$

There has been little in the way of quantitative study of the effects of smoking on human distal airway epithelium; but a single recent semiquantitative study reported increased goblet cell metaplasia in peripheral airways of smokers. ${ }^{18}$ Most of the work on human tissue has been performed on large proximal airways. Several such studies have found a rise in mucus secreting cells (submucosal glands and goblet cells) in smokers. ${ }^{219}$ Other studies, however, have failed to show such changes. ${ }^{20}$ Niewoehner, ${ }^{21}$ in a study on the peripheral airways of young smokers (aged 25-27) meeting sudden accidental death, also failed to show greater numbers of goblet cells than in controls.

It would appear from our results based on a group of smokers of mean age 61.6 (range 49-69) years that there is a significantly increased number of goblet cells in bronchioles but no such significant change in terminal/respiratory bronchioles.

Clara cells were first described by Clara in $1937 . .^{22}$ Since then there have been many electron microscope studies in mice ${ }^{2324}$ and rats $^{2526}$ and in man. They occur mainly in peripheral airways and in a study on large human proximal airways McDowell $e t$ $a l^{27}$ could identify no Clara cells by either light or electron microscopy. In our study Clara cells were present at all levels of distal airways examinednamely, bronchioles and terminal and respiratory bronchioles.

The role of Clara cells is the subject of much debate. It has been suggested that they produce pulmonary surfactant ${ }^{8}$ or a bronchiole-alveolar hypophase layer. Evans $e t$ al, in a study on rat distal airways after exposure to nitrogen dioxide, proposed the Clara cell as a progenitor cell in renewal of bronchiolar epithelium. ${ }^{10}$ After nitrogen dioxide exposure there was evidence of Clara cell proliferation and differentiation to other epithelial cell types. In an earlier experiment the Clara cell number declined after sulphur dioxide exposure, and cells apparently transforming to goblet cells were described. ${ }^{11}$

We have demonstrated that Clara cells comprise a significantly greater percentage of epithelial cells in both bronchioles and terminal and respiratory bronchioles of non-smokers than of smokers. It may be postulated that the reduction in Clara cell numbers observed in smokers could impair small airway function owing to reduced surfactant or hypophase production. This effect, compounded by an increased number of goblet cells, may contribute to the impaired distal airway function in chronic obstructive lung disease.

\section{References}

${ }^{1}$ Jeffrey PK, Reid L. New observations on rat airway epithelium. A quantitative and electron microscope study. J Anat 1975;2:295-320.

${ }^{2}$ Ebert RV, Terracio MJ. The bronchiolar epithelium in cigarette smokers: observations with the scanning electron microscope. Am Rev Respir Dis 1975;111:4-11.

${ }^{3}$ Stephens RJ, Freeman G, Crane SC, Furiosi NJ. Ultrastructural changes in the terminal bronchiole of the rat during continuous low level exposure to nitrogen dioxide. Exp Mol Pathol 1971;14:1-19.

${ }^{4}$ Stephens RJ, Freeman G, Evans MJ. Early response of lung to low levels of nitrogen dioxide. Arch Environ Health 1972;24:160-79.

${ }^{5}$ Lamb D, Reid L. Goblet cell increase in rat bronchiolar epithelium after exposure to cigarette and cigar smoke. Br Med J 1969;i:33.

- Baldwin MA, Lamb D, Evans DP. Effect of a single dose of isoprenaline or salbutamol on airway epithelial goblet cells in the rat. Thorax 1980;35:717.

${ }^{7}$ Widdicombe JG, Park RJ. The Clara cell. Eur J Respir Dis 1982;63:202-20.

${ }^{8}$ Niden AH. Bronchiolar and large alveolar cells in pulmonary phospholipid metabolism. Science 1967; 158:1323-4.

${ }^{9}$ Cutz E, Conen PE. Ultrastructure and cytochemistry of Clara cells. Am J Pathol 1971;62:127-42.

${ }^{10}$ Evans MJ, Cabral-Anderson LJ, Freeman G. Role of Clara cells in the renewal of bronchiolar epithelium. Lab Invest 1978;38:648-55.

" Jeffrey PK, Widdicombe JG, Reid L. Anatomical and physiological features of irritation of the bronchial tree. In: Aharonson EF, Ben David A, Klingberg MA, $\mathrm{Kay} \mathrm{M}$, eds. Air pollution and the lung. Proceedings of 20th Annual OHOLO Biological Conference. New York: Wiley, 1976.

${ }^{12}$ Lamb D, Lumsden AB. Intraepithelial mast cells in human airway epithelium: evidence for smokinginduced changes in their frequency. Thorax 1982;37:334-42.

13 Jones R, Bolduc P, Reid L. Goblet cell glycoprotein and tracheal gland hypertrophy in rat airways. Br J Exp Pathol 1973;54:229-39.

14 Thurlbeck WM, Malaka D, Murphy D. Goblet cells in peripheral airways in chronic bronchitis. Am Rev Respir Dis 1975;112:65-9.

${ }^{15}$ Freeman G, Haydon GB. Emphysema after low level exposure to nitrous oxide. Arch Environ Health 1964;8:125-8.

${ }^{16}$ Sturgess J, Reid L. The effects of isoprenaline and pilocarpine on (a) bronchial mucus secreting tissue, (b) pancreas, salivary glands, heart, thymus, liver and spleen. Br J Exp Pathol 1973;54:388-403.

17 Jones R, Bolduc P, Reid L. Goblet cell glycoprotein and tracheal gland hypertrophy in rat airways. The effect of tobacco smoke with or without anti-inflammatory agent phenylmethyloxadiozole. $\mathrm{Br} J$ Exp Pathol 1973;54:229.

${ }^{18}$ Wright JL, Lawson LM, Pare PD, Wiggs BJ, Kennedy S, Hogg JC. Morphology of peripheral airways in current smokers and ex-smokers. Am Rev Respir Dis 1983;127:474-7.

${ }^{19}$ Auerbach O. Changes in bronchial epithelium in relation 
to sex, age, residence and smoking history. $N$ Engl $J$ Med 1962;262:111-9.

${ }^{20}$ Sobanyo RE, Kleinerman J. Morphometric studies in the bronchi of young smokers. Am Rev Respir Dis 1972; 105:768-75.

${ }^{21}$ Niewoehner PE, Kleinerman J, Rice BD. Pathological changes in the peripheral airways of young cigarette smokers. N Engl J Med 1974;219:755-8.

${ }^{22}$ Clara M. Zur Histobiologie des Bronchalepithels. $Z$ Mikrosk Anat Forsch 1937;41:321-47.

${ }^{23}$ Azzopardi A, Thurlbeck WM. Histochemistry of the non-ciliated bronchiolar epithelial cell. Am Rev Respir Dis 1969;99:516-25.
${ }^{24}$ Petrik P, Collet AJ. Quantitative electron microscopic autoradiography of in vivo incorporation of tritiated choline, tritiated leucine, tritiated acetate and tritiated galactose in non-ciliated bronchiolar cells of mice. Am J Anat 1972;139:519-33.

${ }^{25}$ Smith P, Heath D, Moosavi H. The Clara cell. Thorax 1974;29:147-63.

${ }^{26}$ Kuhn C, Callaway LA, Askin FB. The production of granules in the bronchiolar Clara cell of the rat. $J$ Ultrastruct Res 1974;49:387-400.

${ }^{27}$ McDowell EM, Barratt LA, Glavin F, Harris GC, Trump BF. The respiratory epithelium. I-Human bronchus. J Natl Cancl Inst 1978;61:539-49. 